Portland State University

PDXScholar

Educational Leadership and Policy Faculty

Publications and Presentations

Educational Leadership and Policy

4-2014

\title{
A Missing Piece in the Sustainability Movement: The Human Spirit
}

Deborah S. Peterson

Portland State University, dpeterso@pdx.edu

Follow this and additional works at: https://pdxscholar.library.pdx.edu/elp_fac

Part of the Educational Leadership Commons, Politics and Social Change Commons, and the Sustainability Commons

Let us know how access to this document benefits you.

\section{Citation Details}

Deborah S. Peterson. Sustainability: The Journal of Record. April 2014, 7(2): 74-77. doi:10.1089/ SUS.2014.9810.

This Article is brought to you for free and open access. It has been accepted for inclusion in Educational Leadership and Policy Faculty Publications and Presentations by an authorized administrator of PDXScholar. Please contact us if we can make this document more accessible: pdxscholar@pdx.edu. 


\title{
A Missing Piece in the Sustainability Movement: The Human Spirit
}

\author{
Deborah S. Peterson, EdD
}

Like many sustainability efforts, our urban university rightfully focuses on global as well as local threats to the natural environment.

\section{Introduction}

The sustainability movement, committed to the health of our natural world, is making a critical contribution to society. While many agree the sustainability movement should focus on the natural world, recent articles call for an additional focus on human welfare. This article proposes that a missing piece of the sustainability movement is a discussion of the role of the human spirit. By focusing narrowly on an examination of the state of the natural world, we are neglecting to incorporate the deep and enduring power of the human spirit to transform our natural and human-made environment and to support change agents in the sustainability movement and other social justice movements. Sustaining the human spirit ensures that we each have the hope, clarity of vision, and courage to do challenging work in complex organizations while bringing diverse stakeholders into the conversation during tumultuous times of change. Sustaining the human spirit will result in sustaining our natural world while also creating communities in which the human dignity of each person is honored.

Recognized as a leader in the sustainability movement, Portland State University regularly hosts local, national, and international gatherings of those committed to the principles of sustainability. Like many sustainability efforts, our urban university rightfully focuses on global as well as local threats to the natural environment. This focus is critical for the long-term health of our Earth's ecosystems and perhaps even the survival of the human species. As is common at many Portland events-and is regularly satirized in the popular television show Portlandia-a recent sustainability symposium included locally grown organic food and compostable utensils; committed environmentalists from several generations attended. The agenda for this sustainability symposium focused on grassroots collaboration between university and community partners on projects impacting our local ecodistricts. The symposium was also connected to the university's vision of sustainability:

\begin{abstract}
What is sustainability? Sustainability is a promise that present and future generations will have the opportunity to enjoy productive and rewarding lives. Picture a healthy environment that supports a thriving economy, strong families and vibrant communities, a place where all citizens are valued and engaged in governance. Imagine that these opportunities extend equitably to those in the present generation and are also available for future generations. The environmental, social and economic realms function as an interconnected dynamic system, not as separate parts. ${ }^{1}$
\end{abstract}

In my current role preparing future school leaders, few members of the sustainability movement would automatically classify my area of expertise as sustainability. My initial interest in the sustainability movement included long hours volunteering for a Washington ballot initiative related to the state's nuclear waste industry, employing solar energy in our 1893 home, and receiving the Oregon Elementary School Principals Association Pioneer Award for sustainability programs developed during my tenure as a school principal, which was highlighted in a 2011 film about schools where children learn through gardening. ${ }^{2}$ However, as participants at this sustainability symposium introduced themselves to other guests, it became clear that my philosophy of sustainability included one additional component not mentioned by others: sustainability of the human spirit.

By arguing for the inclusion of the human spirit in the sustainability discussion, I am not proposing that the movement lessen its strong focus on sustainable business practices, green technology, appropriate energy sourcing, recycling programs, sustainable food sourcing, and energy efficient modes of transportation. In fact, in a recent interview with sustainability leaders in higher education and business, this journal's editor Jamie Devereaux, and leading experts in higher education and industry rightfully identified precisely these topics as 
issues critical for survival of our natural world. ${ }^{3}$ Including the concept of the human spirit in sustainability discussions seems to be as uncommon as using the phrase in educational circles. Educators frequently use terms like "common core curriculum," "standardsbased instruction," "student-centered learning," or some type of leadership philosophy, for example, "transformational," "instructional," or "moral leadership." While rare in educational and sustainability professional discourse, in our everyday lives we recognize the role of the spirit by using colloquial phrases such as "keep your spirits up" or calling an active child a "spirited child." On a bad day, we become "dispirited."

Knowing the challenges of leadership for social justice and the many competing demands placed on change agents, why would we neglect or minimize the role of the human spirit in the most important global work of today, the sustainability movement? Marshall adds that despite rarely using the term, the human spirit is at "the very core of who teachers are and what sustains their work with students." ${ }^{4}$ Palmer believes that "the inward and invisible power of the human spirit can have at least equal impact" as the "outward, visible world." In fact, Fang argues that the environmental movement has wrongly focused on nature to the exclusion of "human welfare," a potential limitation that the sustainability movement could avoid by including components of the human spirit in its foundational theory. ${ }^{6}$

I believe that we in the sustainability community could intentionally use the term "human spirit" to describe the sense of honoring our own unique characteristics as well as the human dignity of others; ${ }^{7}$ of nurturing hope in ourselves and others; ${ }^{8}$ and supporting our dreams as well as the dreams of our neighbors, colleagues, and others; ${ }^{9}$ while including the most widely diverse group of people in our sustainability work as envisioned by sustainability leaders at Portland State University, the Evergreen State College, Western Washington University, Edmonds Community College, and the Washington Department of Ecology. ${ }^{10}$ Fang recently noted that the sustainability movement should call for a "revolution in human relations" in an effort to change our demonstrated historic desire to dominate others and to conquer nature, a topic explored in such disparate areas as the literary arts by authors such as Jack London, in indigenous and ancient religions, and in human systems. ${ }^{11}$ I want to add to Fang's call for a revolution in human relations within the sustainability movement by including a focus on sustainability of the human spirit, a topic also explored in disparate disciplines such as design ${ }^{12}$ and school leadership. ${ }^{13}$

One of the main reasons to focus on sustainability of the human spirit in the sustainability movement is that our environmental crisis has been caused by humans. I cannot help but wonder if spiritual disequilibrium in humans contributes to disruption of the natural world. Conversely, it is possible that inner equilibrium or spiritual satisfaction may lead to increasing stewardship of the natural world, as argued by Walker. ${ }^{12}$ To support spiritual satisfaction in the sustainability movement and other social justice movements, I recommend three components of sustainability of the human spirit:

1. Engage the heart and mind of those in our communities.

2. Nurture and sustain those who work as change agents for social justice.

3. Employ ecological or context-specific, culturally responsive strategies to expand the diversity of participants and ensure equitable, democratic participation of all members of our community.

First, as Fang notes, ${ }^{6}$ the sustainability movement should appeal to the heart as well as to the mind of those we're bringing into the sustainability movement, a concept endorsed by other disciplines. Fang notes that even the word sustainability is not "inspirational," perhaps because it seems to imply a technical focus, a focus on the mind, rather than a focus on the people impacted by environmental destruction.

Next, social change of the magnitude and importance of the sustainability movement requires that we intentionally nurture and sustain the change agents who are doing such critical, transformative work. Fang argues, and I agree, that no person or business has the right to remove or limit our access to healthy air, water, and food. ${ }^{6}$ I would also argue that no person or business has the right to reduce or limit another person's sense of hope or to degrade their human spirit.

Like many urban school leaders, my work transforming an underserved high school was complex. One of the most challenging change processes I led was limiting the impact of gang involvement on our school culture. The day I held a student's semi-automatic weapon in my hand was not intellectually challenging or physically taxing; it was spiritually draining for me as well as for the bright, caring young man who was unable to drive off the intense peer pressure to be jumped into the gang. Having a colleague support me spiritually through this failure to keep the youth out of gangs was key to
One of the main reasons to focus on sustainability of the human spirit in the sustainability movement is that our environmental crisis has been caused by humans. I cannot help but wonder if spiritual disequilibrium in humans contributes to disruption of the natural world. 
Ecological, context-based solutions that are identified by those in the community and adapted to the local context are sustainable and more likely to be successful. my continued work. Although quite different, the change process for increasing courses such as music, theatre, creative writing, and collegecredit bearing classes was equally challenging due to district bureaucrats publicly supporting these rigorous and robust programs while simultaneously withholding financial, technical, and moral support. Yet my spirit was sustained by the many youths who told me they "had my back" and by parents and community members who advocated for our work when school bureaucrats did not support our community. Again, I was able to continue my work because my spirit was thriving.

Leading change in communities fearful or distrustful of other social justice or environmental issues can be similarly challenging. Simultaneously working with a sense of urgency, collaborating with those who oppose change, and purposefully pacing the change is stressful. In social justice movements as well as the sustainability movement, we can include a theoretical base, as well as concrete strategies, to support change agents and sustain their spirit.

Most of us, at some point in our personal or professional lives, have experienced a sense of dispirit, have had our personal dignity attacked, or have been less hopeful at the end of the workday than we were at the beginning. It is precisely in these moments that we need change agents who project a sense of connectedness, hope, collective good will, and deep belief in the enduring human values such as love, connectedness, and human dignity. Like Fang, I believe we need leaders to give us words that are "inspiring and aspirational," precisely because this feeds our spirit and gives us hope. Through celebrating the best in each of us and affirming the human dignity in each of us, we can win social justice struggles. Our change agents need to know their leadership matters and that, in community with others, they can lead social justice efforts in our neighborhoods, organizations, and communities.

Because of the deep importance of sustaining hope in our work and connecting with those like us and unlike us as we further the goals of social justice movements, I am proposing additional principles that our organizations and institutions of higher education may also want to consider in sustainability efforts.

\section{Principles of Sustainability of the Human Spirit}

1. Ecological, context-based solutions that are identified by those in the community and adapted to the local context are sustainable and more likely to be successful.
2. Context-based solutions consider the interconnectedness of environmental, social, spiritual, and economic conditions in the community but also understand the community's relationship to a dynamic, changing, complex larger system.

3. We sustain the human spirit when we engage in culturally responsive care for ourselves and for those whom we serve or with whom we work. Culturally responsive care means that each individual engages with others and is engaged by others in ways that honor the human dignity of each unique person.

4. Our spirits thrive when we know ourselves and those around us as unique humans with great potential, and when we or others fail, we provide support to learn from the failure and to grow.

5. The human spirit thrives when we engage in work that builds on our strengths and the strengths of others, strengths that are celebrated and utilized to the benefit of the organization, the individual, our communities, and the sustainability movement.

6. The spirit of our organizations and community thrives when we solicit the perspectives of those whose roles, expertise, experience, age, gender, race, ethnicity, religion, sexual identity, sexual orientation (and other group identifications) differ from the dominant culture or from our own cultural background.

7. Our spirit thrives when we strive to reach consensus, and when we can't, those with the authority to make decisions critically assess who has the power to make the decision, how that person and the decision advantages or disadvantages groups of individuals, and whether the impacted group has been impacted negatively or positively by the dominant culture in our communities, organizations, and society.

8. We express gratitude regularly for what we and others are contributing to and accomplishing in our social justice efforts and are patiently compassionate when we haven't solved all the problems immediately.

9. We have a belief that conflict can result in deepened understandings of ourselves and our relationships with one another, and can expand our commitment to sustainability of our environmental, social, spiritual, and economic systems when we honor the human dignity of each person in our system.

These principles include processes that bring additional stakeholders into the discussion instead of driving them away. They honor the 
Sustaining the human spirit ensures we each have the hope, clarity of vision, and courage to do challenging work in complex interconnected systems and in tumultuous times, work that will result in sustaining our natural world while also honoring the human dignity of each person. human dignity of those who are impacted by decisions. These principles encourage change agents to seek to understand those whose perspectives differ from their own, a key part of the democratic process and an essential next step if the sustainability movement and other social justice efforts are to broaden their support base to include those from the nondominant culture. The principles of sustainability of the human spirit include the philosophy of many diverse fields of study. Finally, sustaining the human spirit ensures we each have the hope, clarity of vision, and courage to do challenging work in complex interconnected systems and in tumultuous times, work that will result in sustaining our natural world while also honoring the human dignity of each person. Following the principles of sustainability of the human spirit may well result in ecological, context-based solutions in all aspects of social justice work, solutions that sustain our natural world and the people in our world, while also honoring the human dignity of each person.

\section{References}

1. Declaration of Support of Sustainability at Portland State University. (http://www.pdx. edu/sustainability/sites/www.pdx.edu.sustainability/files/psu_sust_declaration.pdf) (last accessed 10/30/2013).

2. Gliner B. Lessons from the Real World. 2011. http://www.docmakeronline.com/lessonsfromtherealworld.html (last accessed 10/30/2013).

3. Devereaux J (ed.). Sustainability-focused employee engagement: The experts speak. Sustain J Record 2013;6(3):161-166. http://www.gibbssoell.com/wp-content/uploads/2013/08/Sustainability-Journal-of-Record_June_Roundtable.pdf (last accessed 10/30/2013).

4. Marshall J. Describing the elephant: Preservice teachers talk about spiritual reasons for becoming a teacher. Teacher Educ Q 2009;Spring:38-40.

5. Palmer P. Teaching with Heart and Soul: Reflections on Spirituality in Teacher Education. http://www.couragerenewal.org/parker/writings/heart-and-soul (last accessed 12/04/2013). 6. Fang CC. Beyond sustainability: Communicating a new environmental movement. Sustain J Record 2013;6(6):4. http://online.liebertpub. com.proxy.lib.pdx.edu/doi/pdfplus/10.1089/ SUS.2013.9859 (last accessed 9/26/2013).

7. Gay G. Culturally Responsive Teaching: Theory, Research, and Practice. Teachers College Press, New York, 2010.

8. Duncan-Andrade J. Note to educators: Hope required when growing roses in concrete. Harv Educ Rev 2009;79(2):181-194.

9. Peterson DS. Drafted!: An urban principal's tale. Educ Leadersh 2013;70(7):74-77. 10. MacGregor J, Nolet V, et al. Washington Department of Ecology. Curriculum for the Bioregion Initiative. Sustainability: Big ideas. http://sustainability.utah.edu/getinvolved/faculty/Sustainability_Big_Ideas_2010.pdf (last accessed 10/29/2013).

11. Eisler R. The Chalice and the Blade: Our History, Our Future. Harper \& Row, San Francisco, 2013.

12. Walker S. Design issues: How the other half lives: Product design, sustainability, and the human spirit. 2000;16(1):52-58.

13. Palmer P. To Know as We Are Known: Education as a Spiritual Journey. Harper \& Row, San Francisco, 1983.

Deborah S. Peterson, EdD has won awards for her sustainability and diversity leadership as a school principal as well as for her social justice leadership as an assistant professor in the Graduate School of Education at Portland State University where she prepares future school leaders. 